\title{
PENGARUH FAKTOR INTERNAL DAN EKSTERNAL PERUSAHAAN TERHADAP NILAI PERUSAHAAN
}

\author{
AN EMPIRICAL ANALYSIS OF INTERNAL AND EXTERNAL FACTORS OF FIRM VALUE
}

\author{
Ungkap Rejeki Pasaribu ${ }^{*}$, Nunung Nuryartono ${ }^{* * *}$, dan Trias Andati“**) \\ ${ }^{*}$ Sekolah Bisnis, IPB University \\ Jl. Raya Pajajaran, Bogor 16151 \\ **) Departement Ilmu Ekonomi, Fakultas Ekonomi dan Manajemen, IPB University \\ Jl. Agatis Kampus IPB Darmaga, Bogor 16680 \\ ${ }^{* * *}$ PT. Adhimix Precast Indonesia \\ Jl. Raya Ps. Minggu No. 17A, Pancoran Jakarta Selatan 12780
}

\begin{abstract}
The purpose of this study is to investigate the influence of internal and external factors on the firm value of property and real estate companies listed in Indonesia Stock Exchange. The dependent variable used in this study is Price to Book Value. The Internal factors used in this study are a debt to equity ratio, asset growth, and return on equity, while the external factors used are inflation, exchange rates, and economic growth. The data collected from financial statements of companies in property and real estate companies listed in Indonesia Stock Exchange during the period from 2013 to 2017, and samples were taken from 20 companies. Panel data regression was applied to establish the relationship between dependent and independent variables. The results showed that the internal factors such as debt to equity ratio, return on equity, and asset growth had a significant positive relationship with price to book value. The external factors such as inflation had a significant positive relationship with a price to book value, the exchange rate had a significant negative relationship with a price to book value and the economic growth had no relationship with a price to book value. This study recommends that companies take a policy of using debt as a source of investment financing and also need to improve company performance. Companies need to pay attention and anticipate the changes of external factors, especially exchange rates, because the exchange rate is the most influential factor in the value of the company.
\end{abstract}

Keywords: debt to equity ratio, exchange rate, property, price to book value, return on equity

\begin{abstract}
Abstrak: Penelitian ini bertujuan menguji pengaruh faktor internal dan eksternal perusahaan terhadap nilai perusahaan subsektor properti dan real estate yang terdaftar di Bursa Efek Indonesia. Nilai perusahaan dalam penelitian ini diukur dengan Price to Book Value (PBV). Faktor internal yang dipilih adalah struktur modal yang dihitung dengan Debt Equity Ratio (DER), asset growth, dan profitabilitas yang dihitung dengan Return on Equity (ROE). Sedangkan faktor eksternal yang dipilih adalah inflasi, kurs dan pertumbuhan ekonomi. Pengambilan contoh menggunakan metode purposive sampling dengan kriteria sampel merupakan perusahaan di industri sektor properti dan real estate yang memiliki laporan keuangan periode kuartal tahun 2013 hingga 2017 yang lengkap, dan diperoleh 20 perusahaan. Hasil penelitian menunjukkan bahwa faktor internal DER, ROE, dan asset growth berpengaruh positif terhadap PBV. Faktor eksternal inflasi berpengaruh positif terhadap PBV, sedangkan kurs berpengaruh negatif terhadap PBV, dan PDB tidak berpengaruh terhadap nilai perusahaan. Penelitian ini merekomendasikan perusahaan untuk mengambil kebijakan menggunakan utang sebagai sumber pembiayaan investasi dan juga perlu meningkatkan kinerja perusahaan. Perusahaan perlu memberikan perhatian dan antisipasi terhadap perubahan faktor eksternal, khususnya nilai tukar karena nilai tukar adalah faktor yang paling berpengaruh terhadap nilai perusahaan.
\end{abstract}

Kata kunci: debt to equity ratio, nilai tukar, properti, price to book value, return on equity

\footnotetext{
${ }^{1}$ Corresponding author:

Email: ungkap.pasaribu@gmail.com
} 


\section{PENDAHULUAN}

Sektor properti masih menjadi salah satu pilihan investasi primadona bagi investor. Banyak investasi yang mengalir ke Jakarta, tapi tidak menutup kemungkinan kota besar lainnya di Indonesia juga berkembang dan menarik investasi properti. Di antaranya perhatian pemerintah terhadap kebutuhan rumah lewat program sejuta rumah, pertumbuhan jumlah penduduk, perkembangan infrastruktur dan digitalisasi di dunia bisnis yang makin efisien. Banyaknya proyek infrastruktur yang akan dibangun oleh pemerintah, akan mendorong minat investor menanamkan modalnya di Indonesia, salah satunya adalah investasi dalam sektor properti. Hal ini dibuktikan oleh data terbaru kuartal I tahun 2018 di Indonesia bahwa realisasi investasi pada lima sektor yang paling diminati pada urutan pertama adalah sektor properti yang mencakup perumahan, kawasan industri, dan perkantoran (Gambar 1) .

Data realisasi investasi sektor properti yang dikeluarkan oleh Badan Koordinasi Penanaman Modal (BKPM) juga menunjukkan trend peningkatan pertumbuhan dari tahun 2012 sampai dengan tahun 2017. Pada Gambar 2 dapat dilihat bahwa pada tahun 2017 total penanaman modal asing dan modal dalam negeri pada sektor properti mencapai US\$ 4,171 juta, lebih tinggi 41\% jika dibandingkan dengan tahun 2016 sebesar US\$ 2,955 juta. Penanaman modal asing pada tahun 2017 mencapai US\$ 2,874 juta, naik 23,8\% jika dibandingkan dengan tahun 2016 sebesar US\$ 2,322. Sedangkan penanaman modal dalam negeri pada tahun 2017 mencapai US\$ 1,297 juta, naik 92,6\% jika dibandingkan dengan tahun 2016.

Sementara kontribusi subsektor properti dan real estate terhadap PDB masih relatif kecil, tahun 2017 kontribusi subsektor properti dan real estate adalah sebesar 3,68\% (BPS, 2017). Berdasarkan data BPS menunjukkan bahwa pertumbuhan kontribusi subsektor properti dan real estate mengalami trend yang melambat dalam beberapa tahun terakhir. Adapun pertumbuhan kontribusi PDB subsektor properti dan real estate di Indonesia disajikan pada Gambar 3.

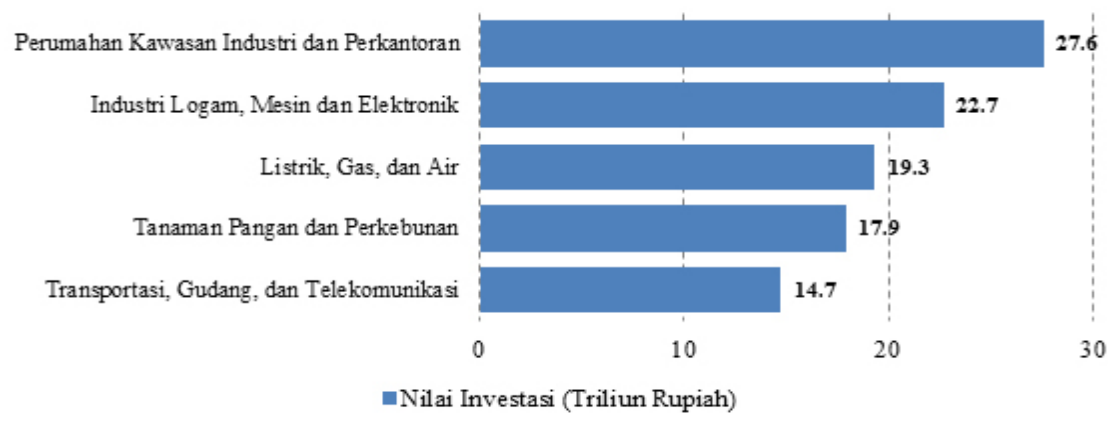

Gambar 1. Realisasi investasi pada lima sektor yang paling diminati, Q1 2018 (BKPM, 2018)

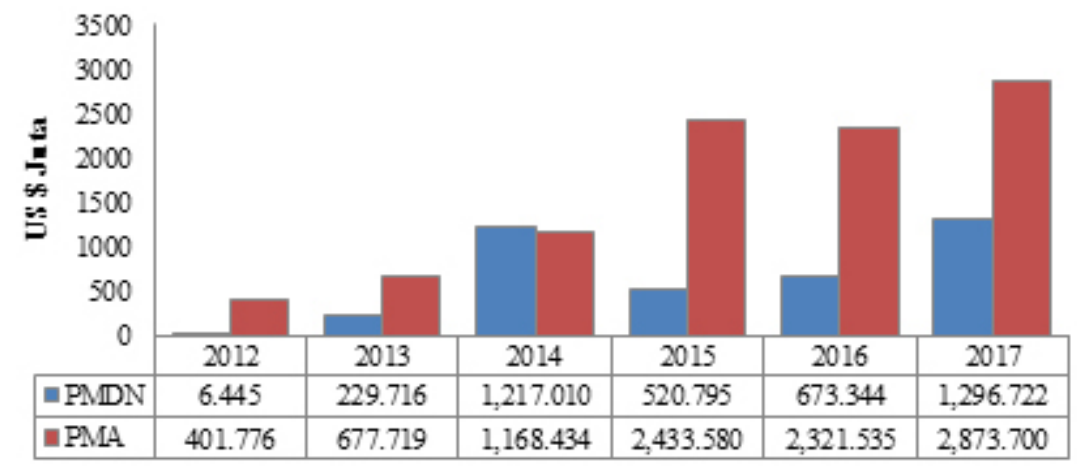

Gambar 2. Tren realisasi investasi sektor properti (BKPM, 2017a; BKPM, 2017b) 


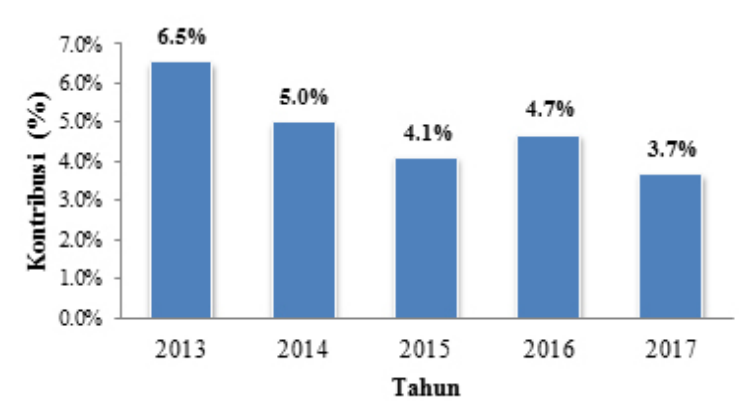

Gambar 3. Kontribusi PDB subsektor properti dan real estate (BPS, 2017)

Perusahaan sektor properti yang sudah go public di Bursa Efek Indonesia (BEI) akan menjaga nilai perusahaan selalu baik dan bahkan meningkat. Hal ini sesuai dengan pernyataan dalam referensi Salvatore (2005) yang menyebutkan bahwa tujuan utama perusahaan yang telah go public adalah meningkatkan kemakmuran pemilik atau pemegang saham melalui peningkatan nilai perusahaan. Nilai perusahaan sangat penting karena mencerminkan kinerja perusahaan yang dapat memengaruhi persepsi investor terhadap perusahaan tersebut. Dengan kata lain, nilai perusahaan adalah persepsi investor terhadap tingkat keberhasilan perusahaan yang sering dikaitkan dengan harga saham.

Salah satu metode yang sering digunakan untuk mengukur nilai perusahaan adalah dengan menghitung price to book value (PBV). PBV adalah perbandingan harga saham dengan harga buku saham, artinya PBV mengambarkan seberapa besar pasar menghargai nilai buku saham suatu perusahaan. PBV menunjukkan seberapa jauh sebuah perusahaan mampu menciptakan nilai perusahaan relative dengan jumlah modal yang diinvestasikan, sehingga semakin tinggi rasio PBV menunjukkan semakin berhasil perusahaanmenciptakan nilai bagi pemegang saham. Rasio PBV yang semakin tinggi mengindikasikan harga saham yang semakin tinggi juga.

Terdapat berbagai variabel yang memengaruhi nilai perusahaan sektor properti yang dapat diklasifikasikan menjadi faktor internal (variabel yang berasal dari emiten atau perusahaan) dan faktor eksternal (variabel yang berada di luar kendali emiten). Kedua faktor tersebut menjadi penting untuk dianalisa karena adanya pergerakan membaik atau memburuknya faktor internal dan faktor eksternal memiliki pengaruh terhadap pergerakan nilai perusahaan emiten sektor properti.
Beberapa penelitian terdahulu terkait dengan pengaruh faktor internal terhadap nilai perusahaan menyimpulkan hasil yang tidak konsisten. Antwi et al. (2012) menyimpulkan bahwa struktur modal berpengaruh positif dan signifikan terhadap nilai perusahaan. Namun, penelitian ini tidak konsisten dengan penelitian yang pernah dilakukan oleh Kodongo et al. (2014) yang membuktikan bahwa struktur modal berpengaruh negatif dan signifikan terhadap nilai perusahaan, sedangkan penelitian yang dilakukan oleh Rasyid (2015) menunjukkan bahwa struktur modal tidak berpengaruh terhadap nilai perusahaan. Penelitian lain terkait dengan pengaruh faktor internal terhadap nilai perusahaan dilakukan oleh Sabrin et al. (2016), Tui et al. (2017), Sucuahi dan Cambarihan (2016). Hasil penelitian mereka menyimpulkan bahwa rasio profitabilitas berpengaruh positifdan signifikan terhadap nilai perusahaan. Berbeda dengan penelitian yang dilakukan oleh Hestinoviana (2013), Herawati (2013) yang menyimpulkan bahwa profitabilitas memiliki pengaruh negatif dan tidak signifikan terhadap nilai perusahaan. Rasio pertumbuhan perusahaan (growth ratios) juga merupakan salah faktor internal yang dapat memengaruhi nilai perusahaan. Dhani dan Utama (2017) menyimpulkan bahwa pertumbuhan perusahaan tidak berpengaruh terhadap nilai perusahaan. Sedangkan penelitian yang dilakukan oleh Paminto et al. (2016), Yuanita et al. (2016) menyimpulkan hal yang berbeda, pertumbuhan perusahaan berpengaruh negatif terhadap nilai perusahaan.

Faktor eksternal yang memengaruhi nilai perusahaan subsektor properti dan real estate diantaranya meliputi variabel makroekonomi. Jika terjadi fluktuasi kondisi variabel makroekonomi maka hal tersebut menjadi peringatan dini yang penting baik bagi investor, pemerintah ataupun emiten untuk mengambil langkah mengantisipasi risiko atas kepentingan masing-masing terkait nilai perusahaan. Tandelilin (2001) menyatakan bahwa faktor ekonomi makro secara empirik telah terbukti mempunyai pengaruh terhadap kondisi pasar modal di beberapa negara. Faktor-faktor tersebut yaitu pertumbuhan ekonomi, inflasi, tingkat suku bunga, dan nilai tukar mata uang atau kurs. Thobarry (2009) dalam penelitiannya menemukan bahwa kurs berpengaruh positif sedangkan inflasi berpengaruh negatif terhadap indeks harga saham subsektor properti dan real estate, sementara suku bunga dan GDP tidak menunjukkan pengaruhnya terhadap indeks harga saham sektor properti. 
Sektor properti merupakan leading indicator bagi ekonomi negara, baik saat mulai bergerak tumbuh maupun ketika pasar turun. Sektor properti di Indonesia masih menjadi salah satu pilihan utama dalam berinvestasi, hal ini dapat dilihat dari realisasi investasi sektor properti yang fluktuatif tetapi memiliki trend meningkat. Namun, jika dilihat dari pertumbuhan PDB sektor properti dan real estate mengalami trend yang menurun. Tujuan utama bagi suatu perusahaan adalah meningkatkan nilai perusahaan. Nilai perusahaan menjadi hal penting bagi pemegang saham karena semakin tinggi nilai perusahaan maka semakin tinggi kemakmuran yang didapat oleh pemegang saham (Brigham dan Gapenski, 2006), semakin tinggi harga saham semakin tinggi pula nilai perusahaan. Salah satu metode untuk menentukan nilai perusahaan adalah dengan menghitung Price to Book Value (PBV). PBV menggambarkan seberapa besar pasar menghargai nilai buku saham suatu perusahaan. Berdasarkan latar belakang yang dikemukakan di atas, maka rumusan masalah dalam penelitian ini adalah bagaimana pengaruh faktor internal dan eksternal terhadap nilai perusahaan pada perusahaan subsektor properti dan real estate yang terdaftar di BEI, dan apa implikasi dari informasi yang dihasilkan bagi emiten dan investor.

Sesuai dengan rumusan masalah yang dikemukaan di atas, maka ada dua tujuan yang ingin dicapai dari penelitian ini. Tujuan pertama adalah menganalisis faktor internal dan eksternal terhadap nilai perusahaan pada perusahaan subsektor properti dan real estate yang terdaftar di BEI. Tujuan kedua adalah memberikan rekomendasi terkait nilai perusahaan bagi emiten dan investor

\section{METODE PENELITIAN}

Data yang digunakan dalam penelitian ini adalah data sekunder, yaitu laporan keuangan kuartalanperusahaan di website BEI periode tahun 2013-2017. Data lain terkait variabel eksternal diambil dari website resmi pemerintah seperti Badan Pusat Statistik (BPS) dan Bank Indonesia (BI). Jenis dan sumber data dapat dilihat pada Tabel 1.

Data yang terkumpul akan diolah dan dianalisa menggunakan metode regresi data panel.Terdapat tiga metode alternatif yang dapat digunakan untuk melakukan estimasi parameter model dengan data panel. Pertama, metode kuadrat terkecil (Pooled Least Square). Kedua, metode efek tetap (Fixed Effect Model). Ketiga, model efek acak (Random Effect Model). Selanjutnya, terdapat tiga uji untuk memilih teknik estimasi data panel. Pertama, Uji Chow yang digunakan untuk memilih antara metode common effect atau fixed effect. Kedua, Uji Hausman yang digunakan untuk memilih antara metode fixed effect atau metode random effect. Ketiga, Uji Lagrange Multiplier (LM) digunakan untuk memilih antata metode common effect atau random effect.

Model yang digunakan dalam penelitian ini adalah sebagai berikut:

$\mathrm{Y}_{\mathrm{it}}=\alpha+\mathrm{b}_{1} \mathrm{X}_{\text {lit }}+\mathrm{b}_{2} \mathrm{X}_{2 \mathrm{it}}+\mathrm{b}_{3} \mathrm{X}_{3 \mathrm{it}}+\mathrm{b}_{4} \mathrm{X}_{4 \mathrm{it}}+\mathrm{b}_{5} \mathrm{X}_{5 \mathrm{it}}+\mathrm{b}_{6} \mathrm{X}_{6 \mathrm{it}}+\mu_{\mathrm{it}}$

Dengan b1, b4, b5 $<0$; b2, b3, b6 $>0$

Tabel 1. Jenis dan sumber data

\begin{tabular}{lccl}
\hline Data Sekunder & Internal/Eksternal & Satuan & Sumber Data \\
\hline Price to Book Value (PVB) & Dependen & Kali & Perhitungan dari laporan keuangan \\
Debt to Equity Ratio (DER) & Internal & Persen & Perhitungan dari laporan keuangan \\
Asset Growth & Internal & Persen & Perhitungan dari laporan keuangan \\
Return on Equity (ROE) & Internal & Persen & Perhitungan dari laporan keuangan \\
Inflasi & Eksternal & Persen & Badan Pusat Statistik (BPS) \\
Nilai tukar & Eksternal & IDR/\$US & Bank Indonesia (BI) \\
PDB & Eksternal & Persen & Badan Pusat Statistik (BPS) \\
\hline
\end{tabular}


Keterangan: $\mathrm{Y}_{\text {it }}$ (Nilai Perusahaan (PBV) untuk perusahaan ke-i dan tahun ke-t); a (Koefisien intersep); i (Sampel); $\mathrm{t}$ (tahun); bx( $\mathrm{x}=1,2,3, \ldots, 6)($ Koefisien slope dari variabel bebas $\mathrm{x}$ ); X1 (Struktur modal (DER)); X2 (Asset growth); X3 (Profitabilitas (ROE)); X4 (Inflasi); X5 (Nilai tukar); X6 (Pertumbuhan ekonomi); $\mu_{\mathrm{it}}$ (Koefisien sisaan satu arah untuk perusahaan ke-i dan tahun ke-t).

\section{Hipotesis Penelitian}

Hipotesis penelitian adalah jawaban sementara terhadap pertanyaan-pertanyaan penelitian yang kebenarannya harus diuji secara empiris. Peneliti akan menguji pengaruh struktur modal, pertumbuhan perusahaan, profitabilitas, inflasi, nilai tukar, pertumbuhan ekonomi terhadap nilai perusahaan. Berdasarkan literaturliteratur yang mendasari penelitian serta hasil penelitian sebelumnya maka hipotesis untuk penelitian ini adalah sebagai berikut:

\section{Pengaruh Struktur Modal terhadap Nilai Perusahaan}

Menurut Apriada (2013) struktur modal berpengaruh negatif dan signifikan terhadap nilai perusahaan pada sektor perusahaan manufaktur. Senada dengan penelitian yang dilakukan oleh Safrida (2008), hasil penelitiannya membuktikan struktur modal memiliki pengaruh negatif dan signifikan terhadap nilai perusahaan. Untuk itu berdasarkan teori di atas dapat dibuat hipotesis sebagai berikut: H1: Struktur modal berpengaruh negatif dan signifikan terhadap nilai perusahaan pada perusahaan sub sektor properti dan real estate yang terdaftar di Bursa Efek Indonesia.

Pengaruh Pertumbuhan Perusahaan terhadap Nilai Perusahaan

Hasil penelitian yang dilakukan oleh Kodongo et al. (2014) dan Hestinoviana (2013) menunjukkan bahwa pertumbuhan perusahaan berpengaruh positif signifikan terhadap nilai perusahaan. Untuk itu berdasarkan teori di atas dapat dibuat hipotesis sebagai berikut: $\mathrm{H} 2$ : Pertumbuhan perusahaan berpengaruh positif dan signifikan terhadap nilai perusahaan pada perusahaan subsektor properti dan real estate yang terdaftar di Bursa Efek Indonesia.

\section{Pengaruh Profitabilitas terhadap Nilai Perusahaan}

Hasil penelitian yang dilakukan oleh Sabrin et al. (2016), Tui et al. (2017), Sucuahi dan Cambarihan (2016), Herawati (2013) menunjukkan bahwa profitabilitas berpengaruh positif dan signifikan terhadap nilai perusahaan. Untuk itu berdasarkan teori di atas dapat dibuat hipotesis sebagai berikut: H3: Profitabilitas berpengaruh positif dan signifikan terhadap nilai perusahaan subsektor properti dan real estate yang terdaftar di Bursa Efek Indonesia.

\section{Pengaruh Inflasi terhadap Nilai Perusahaan}

Hasil penelitian yang dilakukan oleh Thobarry (2009) menunjukkan bahwa variabel inflasi berpengaruh negatif dan signifikan terhadap indeks harga saham. Berdasarkan teori tersebut maka dapat dibuat hipotesis sebagai berikut: H4: Inflasi berpengaruh negatif dan signifikan terhadap nilai perusahaan pada perusahaan subsektor properti dan real estate yang terdaftar di Bursa Efek Indonesia.

\section{Pengaruh Nilai Tukar terhadap Nilai Perusahaan}

Hasil penelitian yang dilakukan oleh Ihsan et al. (2018) dan Kewal (2012) menunjukkan bahwa variable nilai tukar memiliki pengaruh negatif dan signifikan terhadap nilai perusahaan. Berdasarkan penelitian tersebut dapat dibuat hipotesis sebagai berikut: H5: Nilai tukar berpengaruh negatif dan signifikan terhadap nilai perusahaan subsektor properti dan real estate yang terdaftar di Bursa Efek Indonesia.

Pengaruh Pertumbuhan Ekonomi terhadap Nilai Perusahaan

Hasil penelitian yang dilakukan Hooker dan Mark (2004) menunjukkan bahwa pertumbuhan ekonomi memiliki pengaruh terhadap indeks harga saham hal ini mengambarkan bahwa pertumbuhan juga memiliki pengaruh positifterhadap nilai perusahaan. Berdasarkan hasil penelitian tersebut dapat dibuat hipotesis sebagai berikut: H6: Pertumbuhan ekonomi berpengaruh positif dan signifikan terhadap nilai perusahaan pada perusahaan subsektor properti dan real estate yang terdaftar di Bursa Efek Indonesia. 


\section{Definisi Operasional Variabel}

Variabel dependen dalam penelitian ini adalah nilai perusahaan yang dihitung dengan PBV. Variabel independen dalam penelitian ini adalah struktur modal (DER), pertumbuhan perusahaan (asset growth), dan profitabilitas (ROE), inflasi, kurs, dan GDP. Definisi operasional masing-masing variabel dapat dilihat seperti pada Tabel 2.

Tahap pertama penelitian ini adalah dengan mengumpulkan data dari laporan keuangan kuartalan emiten dari tahun 2013-2017 untuk memperoleh data variabel internal. Selanjutnya memperoleh data eksternal dari website BPS dan BI. Faktor internal yang yang digunakan dalam penelitian ini adalah struktur modal (DER), asset growth, profitabilitas (ROE). Sedangkan faktor eksternal yang digunakan adalah inflasi, nilai tukar, dan GDP. Faktor internal dan faktor eksternal tersebut akan dilihat pengaruhnya terhadap nilai perusahaan (PBV). Teknik regresi data panel dilakukan untuk menguji bagaimana pengaruh faktor internal dan eksternal terhadap nilai perusahaan subsektor properti dan real estate yang terdaftar di BEI. Bersadarkan hasil yang diperoleh, dilakukan pembahasan serta dirumuskan implikasi manajerial bagi perusahaan dan investor. Kerangka pemikiran penelitian disajikan seperti Gambar 4.

\section{HASIL}

\section{Pemilihan Model}

Pada regresi data panel, terdapat tiga pilihan model yang dapat digunakan, yaitu Pooled Least Square (PLS), Fixed Effect Model (FEM) dan Random Effect Model (REM). Hasil uji Chow menunjukkan Uji-F maupun Chi Square signifikan $p$-value $=0.0000<0.05$, sehingga dapat disimpulkan bahwa model FEM lebih baik dibandingkan dengan model PLS. Selanjutnya untuk menentukan apakah model terbaik untuk penelitian antara FEM atau REM, maka dilakukan uji Hausman. Hasil uji Hausman menunjukkan hasil warning, dimana variansi dari uji cross section tidak valid, sehingga tidak bisa diambil kesimpulan dengan menggunakan uji Hausman. Sehingga dapat disimpulkan bahwa baik model terbaik yang digunakan untuk penelitian ini adalah model FEM.

\section{Hasil Pengujian Asumsi Klasik}

Pada proses analisa data dengan menggunakan regresi data panel, tahapan lanjutan setelah menentukan model regresi yang tepat digunakan adalah tahap pengujian asumsi klasik. Pengujian ini dilakukan untuk melihat permasalahan yang dapat mengganggu hasil pengolahan dan kesimpulan atau persamaan model yang terbentuk. Pada Tabel 3 dapat dilihat hasil pengujian asumsi klasik yang menunjukkan bahwa Uji normalitas, uji heteroskedastisitas, dan uji autokorelasi telah sesuai dengan kriteria model.

Tabel 1. Definisi operasional variabel

\begin{tabular}{|c|c|c|c|}
\hline No & Variabel & Definisi & Rumus Perhitungan \\
\hline $\mathrm{X} 1$ & Debt to Equity Ratio (DER) & $\begin{array}{l}\text { Struktur modal merupakan perbandingan } \\
\text { antara utang dan ekuitas }\end{array}$ & $\mathrm{DER}=[$ Total hutang $/$ ekuitas $]$ \\
\hline $\mathrm{X} 2$ & Asset Growth & $\begin{array}{l}\text { Pertumbuhan perusahaan adalah perubahan } \\
\text { total aktiva pada periode tertentu }\end{array}$ & $\begin{array}{l}\text { Growth }=[(\text { Total aset tahun } \\
\mathrm{t}-\text { total aset tahun } \mathrm{t}-1) / \text { total aset } \\
\text { tahun sebelumnya }] \times 100 \%\end{array}$ \\
\hline $\mathrm{X} 3$ & Return on Equity (ROE) & $\begin{array}{l}\text { Profitabilitas merupakan kemampuan } \\
\text { perusahaan menghasilkan laba }\end{array}$ & $\mathrm{ROE}=[$ Total laba $/$ ekuitas $]$ \\
\hline $\mathrm{X} 4$ & Inflasi & $\begin{array}{l}\text { Keadaan yang menggambarkan perubahan } \\
\text { tingkat harga dalam sebuah perekonomian. }\end{array}$ & \\
\hline $\mathrm{X} 5$ & Nilai tukar & Nilai tukar rupiah dibandingkan terhadap US\$ & $\begin{array}{l}\text { Kurs nilai tengah }=(\text { Kurs jual }- \\
\text { kurs beli }) / 2\end{array}$ \\
\hline X6 & PDB & Pertumbuhan PDB sektor properti & \\
\hline Y & Price to Book Value (PBV) & $\begin{array}{l}\text { Perbandingan antara harga saham dengan nilai } \\
\text { buku saham }\end{array}$ & $\begin{array}{l}\mathrm{PBV}=[\text { Harga saham / nilai buku } \\
\text { saham }]\end{array}$ \\
\hline
\end{tabular}




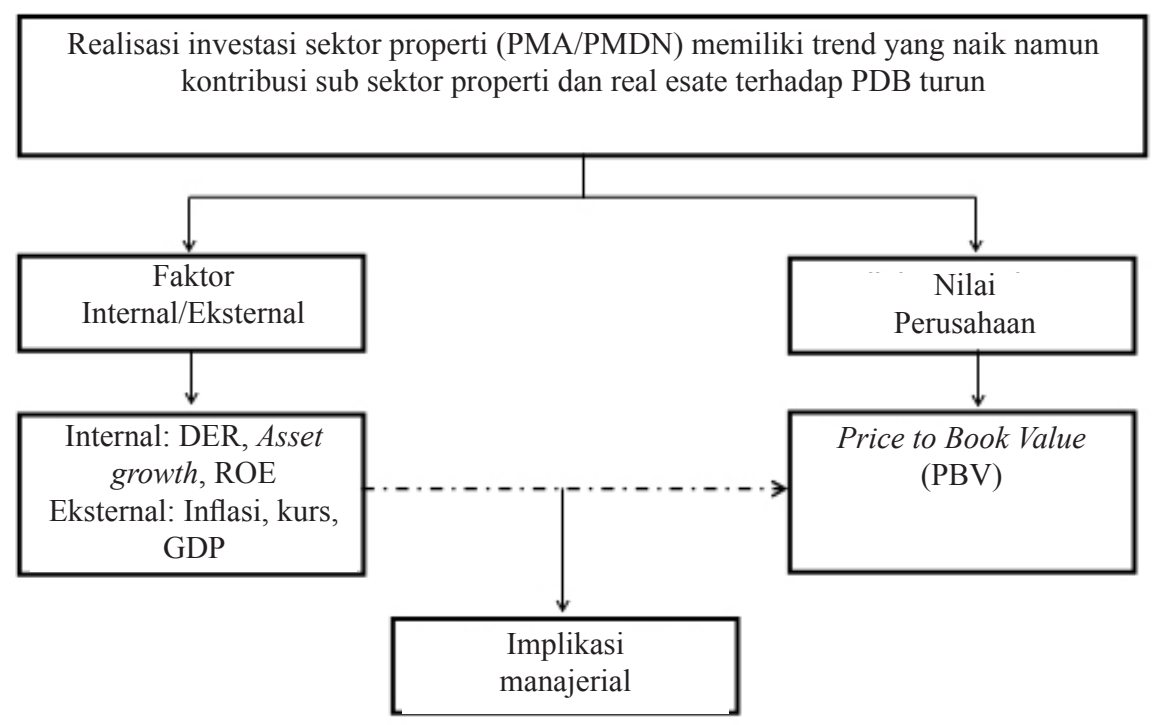

Gambar 4. Kerangka pemikiran penelitian

Tabel 3 Hasil pengujian asumsi klasik

\begin{tabular}{lccc}
\hline & Hasil & Keterangan \\
\hline Uji Normalitas (Probability) & 0,302 & $\mathrm{p}>0,05$ & Sesuai \\
Uji Heteroskedasticitas (Prob. Chi-Square) & 0,1682 & $\mathrm{p}>0,05$ & Sesuai \\
Uji Autokorelasi (Breusch-Godfrey Serial Correlation LM Test-Prob. Chi-Square) & 0,1427 & $\mathrm{p}>0,05$ & Sesuai \\
\hline
\end{tabular}

\section{Uji Multikolinieritas}

Untuk melihat ada atau tidaknya mulitkolinieritas dapat dilakukan dengan cara melihat korelasi antar vaiabel bebas dalam bentuk matriks korelasi. Jika korelasinya kurang dari 0,8 maka dapat disimpulkan bahwa tidak terjadi multikolinieritas. Tabel 4 menampilkan nilai korelasi antar variabel bebas dalam bentuk matriks korelasi. Hasil matriks korelasi dapat dilihat bahwa nilai dari masing-masing variabel yang ada tidak memiliki koefisien yang korelasinya lebih besar dari 0,8 . Sehingga dapat disimpulkan tidak terdapat multikolinieritas antar variabel yang ada.

\section{Hasil Regresi Data Panel}

Model yang digunakan dalam penelitian ini adalah model Fixed Effect Model (FEM). Koefisien determinasi (R-Square) digunakan untuk mengukur kemampuan variabel independen dalam menjelaskan variabel dependen. Pada Tabel 5 di bawah dapat dilihat nilai R-Square adalah 0,9126 yang menunjukkan bahwa variabel independen (DER, growth, ROE, inflasi, kurs, dan GDP) mampu menjelaskan variabel dependen (PBV) sebesar 91,26\%. Sedangkan sisanya 8,74\% dijelaskan oleh variabel lain yang tidak dimasukkan dalam model regresi.Nilai probabilitas dari F-statistik dari model menunjukkan nilai 0,0000 , yang artinya memiliki nilai lebih kecil dari $\alpha$ sebesar 0,10 . Hasil ini menunjukkan bahwa secara serentak semua variabel independen DER (X1), growth (X2), ROE (X3), inflasi (X4), kurs (X5), dan GDP (X6) berpengaruh secara simultan terhadap nilai perusahaan (PBV).

Pengaruh Faktor Internal dan Eksternal terhadap Nilai Perusahaan

Faktor internal perusahaan merupakan faktor yang berasal dari dalam perusahaan sendiri, sehingga sering disebut faktor yang bersifat controllable. Nilai dari faktor-faktor ini dapat diperoleh dengan mengolah data-data yang disajikan dalam laporan keuangan perusahaan. Faktor internal dalam penelitian adalah faktor yang terkait dengan kebijakan perusahaan dan kinerja keuangan perusahaan. Faktor eksternal perusahaan merupakan faktor yang berasal dari luar perusahaan. Faktor-faktor ini tidak dapat dikendalikan oleh perusahaan namun pengaruhnya sangat besar jika terjadi perubahan. 
Tabel 4. Hasil uji multikolinieritas

\begin{tabular}{lcccccc}
\hline & X1 (DER) & X2 (Growth) & X3 (ROE) & X4 (Inflasi) & X5 (Kurs) & X6 (GDP) \\
\hline X1 (DER) & 1,0000 & $(0,0279)$ & 0,1431 & 0,0338 & $(0,0055)$ & 0,0141 \\
X2 (Growth) & $(0,0279)$ & 1,0000 & 0,2723 & 0,1821 & 0,1691 & 0,0418 \\
X3 (ROE) & 0,1431 & 0,2723 & 1,0000 & 0,2762 & 0,3869 & 0,0814 \\
X4 (Inflasi) & 0,0338 & 0,1821 & 0,2762 & 1,0000 & 0,4112 & 0,2771 \\
X5 (Kurs) & $(0,0055)$ & 0,1691 & 0,3869 & 0,4112 & 1,0000 & 0,1301 \\
X6 (GDP) & 0,0141 & 0,0418 & 0,0814 & 0,2771 & 0,1301 & 1,0000 \\
\hline
\end{tabular}

Tabel 5. Hasil regresi data panel pengaruh faktor internal dan eksternal perusahaan terhadap nilai perusahaan

\begin{tabular}{lcc}
\hline Variable & Coefficient & Prob. \\
\hline C & 10,3174 & 0,0000 \\
X1 (DER) & 0,4872 & $0,0000^{*}$ \\
X2 (Growth) & 0,0144 & $0,0758^{*}$ \\
X3 (ROE) & 0,7648 & $0,0000^{*}$ \\
X4 (Inflasi) & 0,1915 & $0,0000^{*}$ \\
X5 (Kurs) & $-1,0657$ & $0,0000^{*}$ \\
X6_(GDP) & 0,0145 & 0,6080 \\
\hline R-squared & 0,9126 & \\
Prob (F-statistic) & 0,0000 & \\
\hline
\end{tabular}

Pengaruh Struktur Modal terhadap Nilai Perusahaan

Struktur modal DER (X1) memiliki nilai koefisien 0,4872 , dan nilai probabilitas 0,0000 kurang dari taraf nyata 0,10 . Artinya, DER berpengaruh positif dan signifikan terhadap nilai perusahaan (PBV). Hasil ini menandakan bahwa setiap kenaikan 1 satuan DER akan menaikkan nilai perusahaan PBV sebesar 0,4685 kali. Artinya kebijakan penambahan utang merupakan sinyal positif bagi investor dan memengaruhi nilai perusahaan. Hasil ini mendukung penelitian Mas'ud (2008), Pertiwi (2018) yang mengatakan bahwa struktur modal berpengaruh positif dan signifikan terhadap nilai perusahaan. Hasil temuan ini juga sejalan dengan teori struktur modal yang dikemukakan oleh Modigliani dan Miller (1958) yang lebih dikenal dengan teori MM yang mengatakan bahwa semakin besar utang yang digunakan maka akan semakin tinggi nilai perusahaan. Dengan demikian hipotesis 1 diterima karena struktur modal berpengaruh positif dan signifikan terhadap nilai perusahaan pada perusahaan subsektor properti dan real estate di BEI.

Secara umum pola pembiayaan perusahaan subsektor properti dan real estate disesuaikan dengan kegiatan pembangunan proyek yang dikerjakan. Pendanaan proyek berasal dari pihak yang memiliki proyek tersebut dan cara pembayaran pada umumnya dilakukan per termin sesuai dengan tingkat penyelesaian proyek. Pola pembayaran seperti ini akan memengaruhi pola pembiayaan perusahaan subsektor properti dan real estate. Apabila perusahaan menggunakan utang untuk membiayai kegiatan tersebut, maka jumlah dan tenor utang akan disesuaikan dengan kebutuhan dana dalam setiap tahapan kegiatan pembangunan dan perjanjian pembayaran per termin yang disepakati oleh pemilik proyek. Skema pembiayaan tersebut akan mengurangi total utang yang harus diperoleh perusahaan sehingga akan mengurangi beban keuangan termasuk beban bunga yang harus ditanggung perusahaan.

Disamping itu, perusahaan properti dan real estate pada umumnya bekerja sama dengan pihak perbankan atau lembaga keuangan lainnya untuk memberikan fasilitas pembiayaan kepada konsumen. Dalam hal ini, konsumen dipersyaratkan untuk membayar lunas sejumlah harga jual properti melalui pembiayaan kredit kepemilikan dari bank atau lembaga keuangan lainnya sebelum proyek diserahkan. Perusahaan akan menerima dana sebesar harga jual dari seluruh real estate yang terjual sebelum pembangunan dimulai. Oleh karena itu, dana yang dibutuhkan oleh perusahaan subsektor properti dan real estate hanya sebesar jumlah yang diperlukan untuk memulai/tahap awal pembangunan, sehingga kalaupun dana tersebut dibiayai dari utang maka jumlah utang yang harus didapatkan jumlahnya relatif kecil dibandingkan dengan kebutuhan dana untuk keseluruhan proyek.

\section{Pengaruh Growth terhadap Nilai Perusahaan}

Variable growth (X2) memiliki nilai koefisien 0,0144 yang artinya pertumbuhan perusahaan berpengaruh positif terhadap nilai perusahaan. Hal ini menandakan setiap kenaikan 1 satuan pertumbuhan perusahaan akan menaikkan nilai perusahaan 0,0144 kali dengan asumsi variabel lain tetap. Nilai probabilitas 0,0758 kurang dari taraf nyata 0,10 . Artinya, pertumbuhan perusahaan 
berpengaruh signifikan. Hal ini bisa terjadi karena pertumbuhan perusahaan yang didefinisikan perubahan total aktiva pada suatu periode, atau peningkatan total aktiva di setiap periodenya. Pertumbuhan aset perusahaan merupakan suatu harapan yang diinginkan oleh pihak internal perusahaan yaitu manajemenmaupun eksternal perusahaan seperti investor dan kreditor. Pertumbuhan ini diharapkan dapat memberikan aspek yang positif bagi perusahaan seperti adanya suatu kesempatan berinvestasi di perusahaan tersebut. Prospek perusahaan yang tumbuh bagi investor merupakan suatu prospek yang menguntungkan, karena investasi yang ditanamkan diharapkan akan memberikan return yang tinggi. Hal ini akan berdampak pada permintaan terhadap saham properti dan real estate akan naik, dan akan menaikkan harga saham perusahaan. Harga saham yang naik akan menaikkan nilai perusahaan yang diukur dengan PBV.

Keputusan investasi yang dilakukan perusahaan akan menentukan keuntungan yang dapat diperoleh perusahaan dan kinerja perusahaan di masa mendatang. Keputusan investasi sangat penting karena jika perusahaan salah dalam pemilihan investasi, maka akan menggangu kelangsungan operasional perusahaan. Oleh karena itu, perusahaan harus menjaga perkembangan investasi sehingga dapat mencapai tujuan perusahaan melalui kesejahteraan pemegang saham dan dapat meningkatkan nilai perusahaan. Hasil penelitian ini sejalan dengan hasil yang ditemukan oleh Hestinoviana (2013) dan Kodongo et al. (2014) yang menemukan pertumbuhan perusahaan berpengaruh positif terhadap nilai perusahaan. Hipotesis ke-2 diterima karena dari hasil penelitian pertumbuhan perusahaan berpengaruh positif dan signifikan terhadap nilai perusahaan.

\section{Pengaruh Profitabilitas terhadap Nilai Perusahaan}

Variabel profitabilitas ROE(X3) memiliki nilaikoefisien 0.7648 menunjukkan bahwa ROE berpengaruh positif terhadap nilai perusahaan. Artinya, Jika ROE naik $1 \%$ maka akan meningkatkan nilai perusahaan PBV sebesar 0.7648 kali, dengan asumsi variabel lain konstan, begitu juga sebaliknya. Nilai probabilitas ROE sebesar 0.0000 kurang dari taraf nyata 0,10 , artinya nilai profitablitas ROE berpengaruh signifikan terhadap nilai perusahaan PBV. Hasil ROE yang tinggi menunjukkan perusahaan menghasilkan keuntungan yang tinggi yang akan memberikan sinyal positif pada investor. Profitabilitas yang tinggi bisa diperkirakan akan menghasilkan deviden yang tinggi bagi pemegang saham. Hal ini bias terjadi karena ketika perusahaan memiliki kinerja keuangan yang baik dan mendapatkan keuntungan yang meningkat maka investor akan tertarik untuk berinvestasi, artinya permintaan akan saham subsektor properti dan real estate jadi meningkat. Permintaan saham yang meningkat akan menaikkan harga saham subsektor properti dan real estate, dan harga saham juga akan meningkat. Harga saham yang meningkat akan menaikkan nilai perusahaan yang diukur dengan PBV. Dengan demikian hipotesis ke 3 diterima karena ROE berpengaruh positif dan signifikan terhadap nilai perusahaan subsektor properti dan real estate yang terdaftar di BEI.

Temuan ini sesuai dengan penelitian yang dilakukan oleh Sabrin et al. (2016), Tui et al. (2017) yang menemukan profitabilitas berpengaruh positif dan signifikan terhadap nilai perusahaan. Temuan ini mengindikasikan bahwa perusahaan berkemampuan menghasilkan laba baik akan cukup memberikan sinyal perusahaan berkinerja baik, dan menjadi daya tarik untuk investor untuk berinvestasi, artinya permintaan akan saham menjadi meningkat, dan nilai perusahaan akan meningkat.

Pengaruh Inflasi terhadap Nilai Perusahaan

Variabel inflasi (X4) memiliki koefisien 0,1915 yang artinya inflasi berpengaruh positif terhadap nilai perusahaan. Hal ini menandakan setiap kenaikan 1 satuan inflasi akan menaikkan nilai perusahaan 0,1915 kali. Nilai probabilitas inflasi sebesar 0,0000 kurang dari taraf nyata 0,10 , artinya inflasi berpengaruh signifikan terhadap nilai perusahaan PBV. Kenaikan inflasi akan berdampak kepada perusahaan subsektor properti dan real estate karena akan mengakibatkan harga bahan bangunan menjadi semakin mahal, menyebabkan biaya produksi yang ditanggung perusahaan menjadi naik. Hal ini akan mengakibatkan margin perusahaan menjadi turun, dan total aktiva perusahaan akan turun. Nilai buku saham perusahaan akan turun dengan turunnya total aktiva perusahaan. Nilai perusahaan yang diukur dengan PBV akan naik dengan turunnya nilai buku saham perusahaan.

Hasil penelitian ini sejalan dengan Yulianto (2015) bahwa inflasi dapat terjadi tidak hanya karena kenaikan biaya melainkan juga tarikan permintaan. Kenaikan inflasi karena tarikan permintaan akan meningkatkan pendapatan bagi perusahaan yang akhirnya akan meningkatkan earning yang dapat dibagikan kepada 
pemegang saham. Hal ini menjadi daya tarik bagi investor dan akan menaikkan permintaan saham sektor properti dan real estate. Kenaikan permintaan saham akan mengakibatkan kenaikan harga saham, dan naiknya harga saham akan menaikkan nilai perusahaan yang diukur dengan PBV. Hasil penelitian ini juga sejalan dengan penelitian yang dilakukan oleh Noerirawan dan Muid (2012) dan Mardiyati dan Rosalina (2013) yang menunjukkan bahwa inflasi berpengaruh positif terhadap nilai perusahaan. Dengan demikian hipotesis ditolak karena inflasi berpengaruh positif dan siknifikan terhadap nilai perusahaan pada perusahaan subsektor properti dan real estate yang terdaftar di BEI.

\section{Pengaruh Nilai Tukar terhadap Nilai Perusahaan}

Variabel nilai tukar (X5) memiliki nilai koefisien -1,057 yang artinya kurs berpengaruh negatif terhadap nilai perusahaan. Hal ini menandakan setiap kenaikan 1 satuan kurs akan menurunkan nilai perusahaan 1.057 kali. Nilai probabilitas kurs sebesar 0,0000 kurang dari taraf nyata 0,10 , artinya kurs berpengaruh signifikan terhadap nilai perusahaan PBV. Ketika mata uang rupiah mengalami pelemahan terhadap mata uang asing (depresiasi) maka akan menaikkan biaya pembelian bahan-bahan bangunan seperti baja, bahan material produk interior dan bahan banguan lain yang diimpor. Hal ini akan menaikkan biaya produksi, dan akan menurunkan kinerja keuangan perusahaan. Penuruan kinerja keuangan akan menurunkan total aktiva perusahaan, dan nilai buku saham yang merupakan selisih dari total aktiva dengan utang per jumlah saham yang beredar tentu akan naik. Nilai perusahaan yang dihitung dengan PBV yaitu perbandingan antara harga saham denga nilai buku saham akan menurun dengan naiknya nilai buku saham.

Begitu juga dengan sebaliknya, penguatan mata uang rupiah terhadap mata uang asing (apresiasi) maka akan menurunkan biaya produksi perusahaan dan akan meningkatkan kinerja perusahaan. Peningkatan kinerja perusahaan akan menaikkan total aktiva dan akan menurunkan nilai buku saham perusahaan. Nilai perusahaan yang diukur dengan PBV akan naik karena nilai buku saham yang turun adalah denominator dalam menghitung PBV.

Melemahnya nilai tukar rupiah terhadap mata uang asing Dollar Amerika berdampak negatif terhadap pasar modal, sehingga menyebabkan pasar modal tidak memiliki daya tarik. Hal ini menyebabkan inverstor beralih ke pasar uang karena return keuntungan yang diperoleh di pasar uang lebih besar dari pada di pasar modal yang pada akhirnya akan menurunkan harga saham. Harga saham yang turun akan berdampak pada nilai perusahaan yang dihitung dengan PBV. PBV akan turun dengan turunnya harga saham perusahaan subsektor properti dan real estate. Hasil penelitian ini sejalan dengan penelitian yang dilakukan oleh Ihsan et al. (2018) dan Kewal (2012) yang menunjukkan bahwa nilai tukar memiliki pengaruh negatif dan signifikan terhadap nilai perusahaan. Dengan demikian hipotesis ke-5 diterima karena kurs berpengaruh negatif dan signifikan terhadap nilai perusahaan pada perusahaan subsektor properti dan real estate yang terdaftar di BEI.

Pengaruh Pertumbuhan Ekonomi terhadap Nilai Perusahaan

Variabel pertumbuhan ekonomi GDP (X6) memiliki nilai koefisien 0,0145 yang artinya pertumbuhan ekonomi berpengaruh positif terhadap nilai perusahaan. Nilai probabilitas GDP sebesar 0,6080 lebih besar dari taraf nyata 0,10 , artinya GDP tidak berpengaruh terhadap nilai perusahaan PBV. Hasil penelitian ini berbeda dengan Hooker (2004) yang menemukan GDP berpengaruh positif dan signifikan terhadap nilai perusahaan. Peningkatan pertumbuhan ekonomi suatu negara mengindikasikan adanya peningkatan kesejahteraan masyarakat di negara tersebut. Adanya peningkatan kesejahteraan masyarakat akan mendorong masyarakat untuk melakukan konsumsi terhadap barang dan jasa sehingga memperluas inbestasi di sektor riil. Adanya perkembangan investasi investasi di sektor riil tidak selalu diikuti adanya peningkatan investasi di pasar modal. Faktor lain yang perlu diperhatikan adalah pemerataan kesejahteraan masyarakat. Peningkatan pertumbuhan ekonomi belum tentu meningkatkan pendapatan per kapita setiap individu sehingga investasi di pasar modal tidak terpengaruh oleh adanya peningkatan pertumbuhan ekonomi.

\section{Rekomendasi terkait Nilai Perusahaan Terhadap Perusahaan dan Investor}

Penelitian terhadap nilai perusahaan memberikan masukan dan tambahan informasi terhadap perusahaan dan investor. Perusahaan dan investor akan mengambil kebijakan masing-masing dengan mempertimbangan nilai perusahaan. Perusahaan akan meningkatkan nilai perusahaannya semakin baik sehingga investor akan 
tertarik untuk berinvestasi. Investor akan melakukan investasi pada perusahaan dengan mengharapkan return dari investasi yang dilakukan.

\section{Perusahaan}

Hasil penelitian menunjukkan bahwa struktur modal yang dihitung dengan DER berpengaruh positif dan signifikan terhadap nilai perusahaan. Artinya, penambahan utang akan menaikkan nilai perusahaan. Oleh karena itu, kebijakan perusahaan menggunakan utang sebagai sumber pembiayaan investasi adalah sangat tepat karena akan meningkatkan nilai perusahaan, hal ini bisa terjadi karena peningkatan pengembalian modal dari investasi tersebut lebih besar dari biaya bunga sebagai beban tetap dari penggunaan utang.

Profitabilitas (ROE) berpengaruh positif dan signifikan terhadap nilai perusahaan, artinya tingkat profitabilitas yang baik menunjukkan perusahaan mempunyai kinerja yang baik dan akan menaikkan nilai perusahaan. Variabel ROE adalah faktor internal yang paling berpengaruh terhadap nilai perusaaan, hal ini dapat dilihat dari nilai koefisien ROE adalah 0,7648 , lebih tinggi dari dua faktor internal lainnya. Oleh karena itu, kebijakan manajerial lebih diarahkan pada upaya peningkatan kinerja perusahaan. Upaya ini dapat dilakukan melalui kebijakan penggunaan utang yang menghasilkan return of rate yang lebih besar dari cost of capital-nya, kebijakan investasi, kebijakan pembagian bonus, dan kebijakan lainnya, agar nilai perusahaan meningkat.

Variabel pertumbuhan perusahaan (growth) dalam penelitian ini diukur dengan perubahan total aset perusahaan dengan periode sebelumnya. Hasil penelitian menunjukkan pertumbuhan perusahaan berpengaruh positif terhadap nilai persuahaan. Artinya kenaikan total aset perusahaan akan menaikkan nilai perusahaan subsektor properti dan real estate yang terdaftar di BEI.

Faktor eksternal inflasi, kurs dan pertumbuhan ekonomi tidak dapat dikendalikan oleh perusahaan. Oleh karena itu, manajemen hanya dapat mengantisipasi perubahan terhadap faktor-faktor eksternal tersebut. Hasil penelitian menunjukkan inflasi berpengaruh positif terhadap nilai perusahaan, artinya ketika inflasi naik maka nilai perusahaan juga naik maka sebaiknya perusahaan menjaga kinerja perusahaan tetap baik.
Variabel kurs berpengaruh negatif dan signifikan terhadap nilai perusahaan. Ketika nilai tukar rupiah mengalami penurunan terhadap mata uang asing (depresiasi), maka harga bahan bangunan yang diimpor akan mengalami kenaikan yang mengakibatkan naiknya biaya produksi perusahaan. Perusahaan sebaiknya mengantisipasi dengan mengurangi impor dan memaksimalkan pembelian bahan bangunan dari dalam negeri. Variabel nilai tukar menjadi faktor yang paling berpengaruh terhadap nilai perusahaan jika dilihat dari besar koefisiennya, dimana nilai tukar memiliki nilai koefiesien -1,0657, paling tinggi dari variabel lain yang diteliti. Artinya, perusahaan perlu memberikan perhatian dan antisipasi terhadap setiap perubahan faktor eksternal, khususnya niali tukar karena akan berpengaruh terhadap perubahan nilai perusahaan.

Investor

Investor yang berinvestasi pada perusahaan subsektor properti dan real estate perlu memperhatikan struktur modal perusahaan tersebut. Sebagaimana dalam penelitian ditemukan bahwa struktur modal berpengaruh positif dan signifikan terhadap nilai perusahaan. Artinya penambahan utang akan menaikkan nilai perusahaan. Penambahan utang perusahaan dapat diartikan perusahaan akan melakukan ekspansi atau perluasan usaha, dengan harapan akan menaikkan kinerja dan meningkatkan nilai perusahaan. Hal ini juga dapat diartikan bahwa penambahan utang dapat menaikkan kinerja perusahaan, dimana peningkatan pengembalian modal lebih tinggi dibandingkan dengan biaya bunga yang dibebankan karena penambahan utang. Bagi investor sebaiknya membeli saham subsektor properti dan real estate ketika perusahaan melakukan penambahan utang, karena akan menaikkan nilai perusahaan di masa depan.

Faktor internal lain yang perlu diperhatikan adalah pertumbuhan perusahaan dan tingkat profitabilitas perusahaan. Hasil penelitian menunjukkan bahwa pertumbuhan dan profitabilitas perusahaan berpengaruh positif dan signifikan terhadap nilai perusahaan. Peningkatan pertumbuhan perusahaan yang besar menandakan adanya ekspansi usaha yang dilakukan, dan akan meningkatkan penjualan dengan harapan akan meningkatkan laba perusahaan. Para investor sebaiknya melakukan pembelian saham perusahaan subsektor properti dan real estate ketika perusahaan menunjukkan kinerja yang baik dengan kata lain memiliki tingkat profitabilitas yang tinggi dan pertumbuhan perusahaan 
yang tinggi juga, karena perusahaan dengan kinerja yang baik memiliki prospek yang baik di masa depan, dan nilai perusahaan akan naik.

Faktor eksternal juga penting jadi bahan pertimbangan bagi investor. Hasil penelitian menunjukkan bahwa variabel inflasi berpengaruh positif dan signifikan terhadap nilai perusahaan subsektor properti dan real estate yang terdaftar di BEI. Artinya, ketika inflasi meningkat maka sebaiknya investor membeli saham sektor properti dan real estate karena nilai perusahaan sektor ini akan meningkat dan sebaliknya.

Variabel nilai tukar rupiah berpengaruh negatif dan signifikan terhadap nilai perusahaan, hal ini sesuai dengan hipotesis penelitian. Ketika nilai tukar rupiah mengalami penurunan terhadap mata uang asing (depresiasi), maka sebaiknya investor menjual saham sektor properti dan real estate karena nilai perusahaan sektor ini akan turun. Sebaliknya, jika nilai tukar rupiah mengalami kenaikan terhadap mata uang asing (apresiasi), maka sebaiknya investor membeli saham sektor properti dan real estate karena harga saham akan meningkat dan nilai perusahaan juga akan meningkat.

\section{Implikasi Manajerial}

Kebijakan perusahaan menggunakan utang sebagai sumber pembiayaan investasi adalah sangat tepat karena akan meningkatkan nilai perusahaan, hal ini bisa terjadi karena peningkatan pengembalian modal dari investasi tersebut lebih besar dari biaya bunga sebagai beban tetap dari penggunaan utang. Profitabilitas (ROE) berpengaruh positif dan signifikan terhadap nilai perusahaan, kebijakan manajerial lebih diarahkan pada upaya peningkatan kinerja perusahaan. Upaya ini dapat dilakukan melalui kebijakan penggunaan utang yang menghasilkan return of rate yang lebih besar dari cost of capital-nya, kebijakan investasi, kebijakan pembagian bonus, dan kebijakan lainnya, agar nilai perusahaan meningkat. Hasil penelitian menunjukkan pertumbuhan perusahaan berpengaruh positif terhadap nilai persuahaan. Artinya, kenaikan total aset perusahaan akan menaikkan nilai perusahaan.

Investor yang berinvestasi pada perusahaan subsektor properti dan real estate perlu memperhatikan struktur modal perusahaan tersebut. Sebagaimana dalam penelitian ditemukan bahwa struktur modal berpengaruh positif dan signifikan terhadap nilai perusahaan. Penambahan utang perusahaan dapat diartikan perusahaan akan melakukan ekspansi atau perluasan usaha, dengan harapan akan menaikkan kinerja dan meningkatkan nilai perusahaan. Hasil penelitian menunjukkan bahwa pertumbuhan dan profitabilitas perusahaan berpengaruh positif dan signifikan terhadap nilai perusahaan. Peningkatan pertumbuhan perusahaan yang besar menandakan adanya ekspansi usaha yang dilakukan, dan akan meningkatkan penjualan dengan harapan akan meningkatkan laba perusahaan. Para investor sebaiknya melakukan pembelian saham perusahaan subsektor properti dan real estate ketika perusahaan menunjukkan kinerja yang baik dengan kata lain memiliki tingkat profitabilitas yang tinggi dan pertumbuhan perusahaan yang tinggi juga, karena perusahaan dengan kinerja yang baik memiliki prospek yang baik di masa depan, dan nilai perusahaan akan naik.

\section{KESIMPULAN DAN SARAN}

\section{Kesimpulan}

Hasil dari penelitian ini dapat disimpulkan bahwa faktor internal perusahaan, yaitu struktur modal (DER), asset growth, dan profitabilitas (ROE) berpengaruh positif terhadap nilai perusahaan price to book value (PBV). Faktor eksternal perusahaan yaitu inflasi berpengaruh positif, sementara kurs berpengaruh negatif dan pertumbuhan PDB tidak berpengaruh terhadap nilai perusahaan. Rekomendasi yang bisa diberikan kepada perusahaan dan investor adalah sebagai berikut. Ketika nilai tukar rupiah mengalami depresiasi, perusahaan sebaiknya mengantisipasi dengan memaksimalkan pembelian bahan bangunan dari dalam negeri atau dengan kata lain mengurangi impor. Bagi investor sebaiknya menjual saham sektor properti dan real estate untuk meminimalkan resiko nilai perusahaan turun. Faktor kedua yang paling berpengaruh terhadap nilai perusahaan adalah kinerja perusahaan (ROE). Upaya peningkatan kinerja perusahaan dapat dilakukan melalui kebijakan penggunaan utang (meningkatkan DER) dan kebijakan investasi (meningkatkan Growth).

\section{Saran}

Perusahaan sebaiknya memberikan perhatian lebih terhadap kebijakan peningkatan nilai ROE karena variabel ini merupakan faktor internal yang paling berpengaruh terhadap nilai perusahaan. Ketika nilai tukar rupiah mengalami penurunan terhadap mata 
uang asing (depresiasi), maka sebaiknya investor menjual saham sektor properti dan real estate karena nilai perusahaan sektor ini akan turun. Sebaliknya, jika nilai tukar rupiah mengalami kenaikan terhadap mata uang asing (apresiasi), maka sebaiknya investor membeli saham sektor properti dan real estate karena harga saham akan meningkat dan nilai perusahaan juga akan meningkat.Ketika nilai tukar rupiah mengalami penurunan terhadap mata uang asing (depresiasi), perusahaan sebaiknya mengantisipasi dengan mengurangi impor dan memaksimalkan pembelian bahan bangunan dari dalam negeri untuk menjaga nilai perusahaan tetap baik. Bagi peneliti berikutnya dapat melakukan penelitian lebih lanjut tentang struktur modal optimal pada perusahaan subsektor properti dan real estate.

\section{DAFTAR PUSTAKA}

Antwi S, Mills EFEA, Zhao X. 2012. Capital structure and firm value: Empirical evidence from Ghana. International Journal of Business and Social Science. 3(22): 103-111.

Apriada K. 2013. Pengaruh struktur kepemilikan, struktur modal dan profitabilitas pada nilai perusahaan [tesis]. Denpasar: Universitas Udayana.

Brigham EF, Gapenski LC. 2006. Intermediate Financial Management.7 $\neg$ th edition. SeaHarbor Drive: The Dryden Press

[BKPM] Badan Koordinasi Penanaman Modal. 2017a. Tren realisasi investasi luar negeri sektor properti. https://www.bkpm.go.id/id/statistik/investasilangsung-luar-negeri-fdi [2018 Januari 20].

[BKPM] Badan Koordinasi Penanaman Modal. 2017b. Tren realisasi investasi dalam negeri sektor properti. https://www.bkpm.go.id/id/statistik/ investasi-langsung-dalam-negeri-ddi [2018 Januari 20].

[BPS] Badan Pusat Statistik. 2017. Pertumbuhan PDB sektor properti 2017-2018.https://www. bps.go.id/dynamictable/2017/05/05/1255/seri-2010-laju-pertumbuhan-y-on-y-produkdomestik-bruto-menurut-lapangan-usaha-\%2017---2018.html [2018 Januari 20].

Dhani IP, Utama AG. 2017. Pengaruh pertumbuhan perusahaan, struktur modal, dan profitabilitas, terhadap nilai perusahaan. Jurnal Riset Akuntansi dan Bisnis Airlangga 2(1): 135-148. https://doi. org/10.31093/jraba.v2i1.28.
Herawati T. 2013. Pengaruh kebijakan dividen, kebijakan hutang dan profitabilitas terhadap nilai perusahaan. Jurnal Manajemen 2(2): 1-18.

Hestinoviana V. 2013. The influence of profitability, solvability, asset growth, and sales growth toward firm value (empirical study on mining companies which listed on indonesia stock exchange). Jurnal Administrasi Bisnis 4(1).

Hooker, Mark A. 2004. Macroeconomic factors and emerging market equity returns: a bayesian model selection approach. Emerging Markets Review 5: 379-387.https://doi.org/10.1016/j. ememar.2004.09.001.

Ihsan H, Rashid A, Naz A. 2018. Exchange rate exposure and firm value: an assesment of domestic versus multinational firms. The Lahore Journal of Economics 23(1): 51-77. https://doi. org/10.35536/lje.2018.v23.i1.A3.

Kewal SS. 2012. Pengaruh inflasi, suku bunga, kurs, dan pertumbuhan PDB terhadap indeks harga saham gabungan. Jurnal economia 8(1):53-64.

Kodongo O, Mokoaleli-Mokoteli T, Maina LN. 2014. Capital structure, profitability and firm value: panel evidence of listed firms in Kenya. African Finance Journal 17(1): 1-20.https://doi. org/10.2139/ssrn.2465422

Mardiyati U, Rosalina A. 2013. Analisis pengaruh nilai tukar, tingkat suku bunga dan inflasi terhadap indeks harga saham studi kasus pada perusahaan properti yang terdaftar di bursa efek Indonesia. Jurnal Riset Manajemen Sains Indonesia 4(1): $1-15$.

Mas'ud M. 2008. Analisis faktor-faktor yang memengaruhi struktur modal dan hubungannya terhadap nilai perusahaan. Jurnal Manajemen dan Bisnis 7(4): 82-99.

Modigliani F, Miller MH. 1958. The cost of capital, corporation finance, and the theory of investment. American Economics Review 13 (3): 261-297.

Noerirawan, Ronni dan Muid, Abdul, 2012. Pengaruh faktor internal dan eksternal perusahaan terhadap nilai perusahaan. Journal of Accounting 1(1): 1-12.

Paminto A, Setyadi D, Sinaga J. 2016. The effect of capital structure, firm growth, and dividend policy in profitability and firm value of the palm oil plantation companies in Indonesia. European Journal of Business and Management 8(33): 123-134.

Pertiwi YI. 2018. Pengaruh kinerja keuangan terhadap nilai perusahaan sektor properti, real estate, dan 
konstruksi bangunan [tesis]. Bogor: Institut Pertanian Bogor

Rasyid A. 2015. Effects of ownership structure, capital structure, profitability and company's growth towards firm value. International Journal of Business and Management Invention 4(4): 2531.

Sabrin SB, Dedy TS, Sujono. 2016. The effect of profitability on firm value in manufacturing company at Indonesia stock exchange. The International Journal of Engineering And Science 5(10): 81-89.

Safrida E. 2008. Pengaruh struktur modal dan pertumbuhan perusahaan terhadap nilai perusahaan pada perusahaan manufaktur di bursa efek jakarta [tesis]. Medan: Universitas Sumatera Utara.

Salvatore D. 2005. Ekonomi Manajerial dalam Perekonomian Global. Setyo BI, penerjemah. Jakarta: Salemba Empat. Terjemahan dari: Manajerial Economics.

Sucuahi W, Cambarihan JM. 2016. Influence of profitability to the firm value of diversified companies in Philippines. Accounting and
Finance Research 5(2): 149-153.https://doi. org/10.5430/afr.v5n2p149.

Tandelilin E. 2001. Analisis Investasi dan Manajemen Portofolio. Yogyakarta: PBFE.

Thobarry AA. 2009. Analisis pengaruh nilai tukar, suku bunga, laju inflasi dan pertumbuhan GDP terhadap indeks harga saham sektor properti (kajian empiris pada bursa efek indonesia periode pengamatan tahun 2000-2008) [tesis]. Semarang: Universitas Diponegoro.

Tui S, Nurnajamuddin M, Sufri M, Nirwana A. 2017. Determinants of profitability and firm value: Evidence from Indonesian banks. International Journal of Management \& Social Science 7(1): 84-95.https://doi.org/10.21013/jmss.v7.n1.p10.

Yuanita, Budiyanto, Riyadi S. 2016. Influence of capital structure, size and growth on profitability and corporate value. International Journal of Business and Finance Management Research 4(1): 80-101.

Yulianto D. 2015. Pengaruh kinerja perusahaan dan variabel makroekonomi terhadap harga saham perbankan. Jurnal Aplikasi Manajemen 5(2): 3-15. 